\title{
Article
}

\section{Analysis of Missense Variants in the Human Histamine Receptor Family Reveals Increased Constitutive Activity of E410 ${ }^{6.30 \times 30} \mathrm{~K}$ Variant in the Histamine $\mathrm{H}_{1}$ Receptor}

\author{
Xiaoyuan Ma ${ }^{+}\left(\mathbb{D}\right.$, Marta Arimont Segura ${ }^{\dagger}$, Barbara Zarzycka, Henry F. Vischer $(\mathbb{D}$ and Rob Leurs *(i) \\ Division of Medicinal Chemistry, Faculty of Science, Amsterdam Institute for Molecules, Medicines and Systems, \\ Vrije Universiteit Amsterdam, 1081 HZ Amsterdam, The Netherlands; x.ma@vu.nl (X.M.); \\ m.arimontsegura@vu.nl (M.A.S.); b.a.zarzycka@vu.nl (B.Z.); h.f.vischer@vu.nl (H.F.V.) \\ * Correspondence: r.leurs@vu.nl \\ + Both authors contributed equally.
}

check for

updates

Citation: Ma, X.; Segura, M.A.; Zarzycka, B.; Vischer, H.F.; Leurs, R. Analysis of Missense Variants in the Human Histamine Receptor Family Reveals Increased Constitutive Activity of $\mathrm{E} 410^{6.30 \times 30} \mathrm{~K}$ Variant in the Histamine $\mathrm{H}_{1}$ Receptor. Int. J. Mol. Sci. 2021, 22, 3702. https://doi.org/ $10.3390 /$ ijms 22073702

Academic Editor: Francisco Ciruela

Received: 24 February 2021

Accepted: 26 March 2021

Published: 2 April 2021

Publisher's Note: MDPI stays neutral with regard to jurisdictional claims in published maps and institutional affiliations.

Copyright: (c) 2021 by the authors. Licensee MDPI, Basel, Switzerland. This article is an open access article distributed under the terms and conditions of the Creative Commons Attribution (CC BY) license (https:// creativecommons.org/licenses/by/ $4.0 /)$.
Abstract: The Exome Aggregation Consortium has collected the protein-encoding DNA sequences of almost 61,000 unrelated humans. Analysis of this dataset for G protein-coupled receptor (GPCR) proteins (available at GPCRdb) revealed a total of 463 naturally occurring genetic missense variations in the histamine receptor family. In this research, we have analyzed the distribution of these missense variations in the four histamine receptor subtypes concerning structural segments and sites important for GPCR function. Four missense variants $R 127^{3.52 \times 52} \mathrm{H}, \mathrm{R} 139^{34.57 \times 57} \mathrm{H}, \mathrm{R} 409^{6.29 \times 29} \mathrm{H}$, and $\mathrm{E} 410^{6.30 \times 30} \mathrm{~K}$, were selected for the histamine $\mathrm{H}_{1}$ receptor $\left(\mathrm{H}_{1} \mathrm{R}\right)$ that were hypothesized to affect receptor activity by interfering with the interaction pattern of the highly conserved $D(E) R Y$ motif, the so-called ionic lock. The $\mathrm{E} 410^{6.30 \times 30} \mathrm{~K}$ missense variant displays higher constitutive activity in $\mathrm{G}$ protein signaling as compared to wild-type $\mathrm{H}_{1} \mathrm{R}$, whereas the opposite was observed for $\mathrm{R} 127^{3.52 \times 52} \mathrm{H}$, $\mathrm{R} 139^{34.57 \times 57} \mathrm{H}$, and $\mathrm{R} 409^{6.29 \times 29} \mathrm{H}$. The $\mathrm{E} 410^{6.30 \times 30} \mathrm{~K}$ missense variant displays a higher affinity for the endogenous agonist histamine than wild-type $\mathrm{H}_{1} \mathrm{R}$, whereas antagonist affinity was not affected. These data support the hypothesis that the $\mathrm{E} 410^{6.30 \times 30} \mathrm{~K}$ mutation shifts the equilibrium towards active conformations. The study of these selected missense variants gives additional insight into the structural basis of $\mathrm{H}_{1} \mathrm{R}$ activation and, moreover, highlights that missense variants can result in pharmacologically different behavior as compared to wild-type receptors and should consequently be considered in the drug discovery process.

Keywords: missense variation; $\mathrm{G}$ protein-coupled receptor; histamine $\mathrm{H}_{1}$ receptor; ionic lock; constitutive activity

\section{Introduction}

G protein-coupled receptors (GPCRs) constitute the largest family of membrane proteins encoded by the human genome and play a dominant role in regulating human physiology in response to extracellular stimuli [1]. Consequently, GPCRs are well-established targets for therapeutic intervention with approximately $35 \%$ of all United States Food and Drug Administration (USFDA)- and European Medicines Agency (EMA)-approved drugs acting via one or more GPCR subtypes [2,3].

A recent analysis of the protein-coding DNA sequence (exome) of nearly 61,000 unrelated individuals in the exome aggregation consortium (ExAC) database [4] revealed 65,539 missense variations (MV) in the total GPCR family with on average 155.0 rare (single observations or minor allele frequency $(\mathrm{MAF})<1 \times 10^{-3}$ ) and 4.8 commons (MAF $\geq 1 \times 10^{-3}$ ) MVs per GPCR subtype (https:/ / gpcrdb.org/mutational_landscape/ statistics; accessed on 20 January 2021) (Table 1) [5]. These naturally occurring GPCR variants may display differences in ligand binding, basal activity, signaling, trafficking, and/or expression, as compared to the most frequently occurring wild-type receptor [5]. Hence, 
individuals in the population might respond differently to medicines due to these genetic variations in their target GPCRs. Indeed, sorting intolerant from tolerant (SIFT; $\leq 0.05)$ and polymorphism phenotyping (PolyPhen; $\geq 0.1$ ) analyses predicted that $67.1 \%$ (9522 of the 14,192) of the MVs identified in 108 GPCR with USFDA-approved drugs in 2017 might affect receptor functioning [5]. Of these MVs, 1722 were found to map to ligand-binding pockets, $\mathrm{G}$ protein and/or $\beta$-arrestin interaction interface, allosteric sodium-binding pocket, microswitches that are involved in receptor conformational change, and post-translational modification sites [5]. Indeed, variants of the $\mu$-opioid and cholecystokinin-A receptors displayed distinct drug responses in transfected cells [5].

Table 1. Missense variations (MV) in G protein-coupled receptors (GPCR) from nearly 61,000 unrelated individuals in the exome aggregation consortium (ExAC) database.

\begin{tabular}{|c|c|c|c|c|c|c|}
\hline & $\begin{array}{l}\text { Total Missense } \\
\text { Variations }\end{array}$ & $\begin{array}{c}\text { Average } \\
\text { Density }{ }^{1}\end{array}$ & $\begin{array}{c}\text { Total Rare } \\
\text { MVs }^{2}\end{array}$ & $\begin{array}{c}\text { Total Common } \\
\text { MVs }^{3}\end{array}$ & $\begin{array}{c}\text { Predicted } \\
\text { Deleterious } \\
\text { Mutations }\end{array}$ & $\begin{array}{c}\text { Total Loss-of- } \\
\text { Function } \\
\text { Variants }\end{array}$ \\
\hline All GPCRs ${ }^{6}$ & 65,539 & 0.27 & $155^{7}$ & $4.8^{7}$ & & 4066 \\
\hline Class A GPCRs ${ }^{8}$ & 36,340 & 0.27 & 35,323 & 1017 & 24,207 & 2305 \\
\hline $\begin{array}{l}\text { Histamine } \\
\text { receptors }\end{array}$ & 463 & 0.24 & 453 & 10 & 289 & 30 \\
\hline $\mathrm{H}_{1} \mathrm{R}$ & 154 & 0.32 & 149 & 5 & 86 & 6 \\
\hline $\mathrm{H}_{2} \mathrm{R}$ & 71 & 0.20 & 70 & 1 & 36 & 1 \\
\hline $\mathrm{H}_{3} \mathrm{R}$ & 117 & 0.26 & 117 & 0 & 83 & 2 \\
\hline $\mathrm{H}_{4} \mathrm{R}$ & 121 & 0.31 & 117 & 4 & 84 & 21 \\
\hline
\end{tabular}

${ }^{1}$ Absolute count/length of receptor. ${ }^{2}$ Minor allele frequency (MAF) $<1 \times 10^{-3} .{ }^{3}$ Minor allele frequency (MAF) $\geq 1 \times 10^{-3} .{ }^{4}$ sorting intolerant from tolerant (SIFT) and polymorphism phenotyping (PolyPhen) scoring systems are algorithms that predict the impact of missense variation on protein structure and function. SIFT $\leq 0.05$ or PolyPhen $\geq 0.1$ is considered deleterious. ${ }^{5}$ Loss of function mutations are frame-shift mutation or introduced stop codon. ${ }^{6}$ All 401 non-olfactory GPCRs. ${ }^{7}$ Average per receptor. ${ }^{8} 290$ class A GPCRs.

The endogenous biogenic amine histamine is an important regulator in various (patho)physiological processes by acting via the GPCR subfamily of histamine receptors that consist of the histamine $\mathrm{H}_{1}, \mathrm{H}_{2}, \mathrm{H}_{3}$, and $\mathrm{H}_{4}$ receptor $\left(\mathrm{H}_{1} \mathrm{R}, \mathrm{H}_{2} \mathrm{R}, \mathrm{H}_{3} \mathrm{R}\right.$, and $\left.\mathrm{H}_{4} \mathrm{R}\right)$ [6]. The $\mathrm{H}_{1} \mathrm{R}$ and $\mathrm{H}_{2} \mathrm{R}$ are long-known drug targets with antagonists being developed in the 1930s and 1970s, respectively [7]. In fact, the $\mathrm{H}_{1} \mathrm{R}$ has the highest number (73) of approved drugs listed in the "drug-target classification tree" on the GPCRdb website (https://gpcrdb.org/drugs/drugmapping; accessed on 20 January 2021) [3,8]. The majority of these $\mathrm{H}_{1} \mathrm{R}$ drugs are used to relieve allergic reactions by antagonizing $\mathrm{H}_{1} \mathrm{R}$-mediated contraction of airway smooth muscles and increasing vascular permeability in response to histamine, which is released from mast cells upon allergen binding, but also in the treatment of nausea and vomiting [6]. Moreover, 14 approved drugs are listed in the "GPCRdb drug-target classification tree" for the $\mathrm{H}_{2} \mathrm{R}$, of which some are "blockbuster" drugs for the treatment of peptic ulcer and gastroesophageal reflux disease by antagonizing $\mathrm{H}_{2} \mathrm{R}$-mediated gastric acid secretion in response to histamine [6]. The $\mathrm{H}_{3} \mathrm{R}$ and $\mathrm{H}_{4} \mathrm{R}$ were more recently discovered in the 1980s and 2000, respectively [6]. The $\mathrm{H}_{3} \mathrm{R}$ is involved in the regulation of neurotransmission and has been associated with Parkinson's and Alzheimer's diseases, epilepsy, learning and sleeping disorders [6]. Although several clinical trials with $\mathrm{H}_{3} \mathrm{R}$ ligands have been reported in the last decade [9], hitherto only pitolisant (Wakix ${ }^{\circledR}$ ) has been approved in 2016 and 2019 by the EMA and USFDA, respectively, for the treatment of narcolepsy $[10,11]$. The $\mathrm{H}_{4} \mathrm{R}$ is involved in immunomodulation, and several antagonists are currently in a clinical trial for the treatment of itch, psoriasis, atopic dermatitis, rheumatoid arthritis, allergic rhinitis, and asthma [12].

The ExAC dataset analysis revealed 463 genetic missense variants in the histamine receptor family (Table 1) [5]. In this paper, we first report on the analysis of these genetic variants in the histamine receptor family and provide an experimental example for the $\mathrm{H}_{1} \mathrm{R}$ how these natural variants can contribute to the understanding of GPCR function. 


\section{Results}

\subsection{Genetic Missense Variations in the Histamine Receptor Family}

Analysis of the ExAC dataset revealed 154, 71, 117, and 121 genetic missense variants (MVs) for the $\mathrm{H}_{1} \mathrm{R}, \mathrm{H}_{2} \mathrm{R}, \mathrm{H}_{3} \mathrm{R}$, and $\mathrm{H}_{4} \mathrm{R}$, respectively (Figure 1, Table 1) [5]. Most of these $453 \mathrm{MVs}$ are rare with a minor allele frequency (MAF) $<1 \times 10^{-3}$, whereas only $10 \mathrm{MVs}$ are considered common with a MAF score $\geq 1 \times 10^{-3}$ (Table 1). Five common MVs were observed in the N-terminal tail (i.e., M14I, K19N) and ICL3 (i.e., G270E, R326Q, $\mathrm{D} 349 \mathrm{H})$ of $\mathrm{H}_{1} \mathrm{R}$, one common MV in TM7 (N266 $\left.{ }^{7.31 \times 30} \mathrm{~S}\right)$ of $\mathrm{H}_{2} \mathrm{R}$, and four common MVs in TM3 (V88 $\left.{ }^{3.26 \times 26} \mathrm{G}\right), \mathrm{TM} 4\left(\mathrm{~A} 138^{4.48 \times 48} \mathrm{~V}\right)$, TM5 $\left(\mathrm{H} 206^{5.70 \times 70} \mathrm{R}\right)$ and ICL3 (S284C) of $\mathrm{H}_{4} \mathrm{R}$ (Supplementary Figure S1). Interestingly, approximately half of the MVs in the $\mathrm{H}_{1} \mathrm{R}$ and $\mathrm{H}_{2} \mathrm{R}(55.8 \%$ and $50.7 \%$, respectively) were predicted to have a functional impact based on their SIFT $(0-0.05)$ and / or PolyPhen $(>0.1)$ scores, whereas more than two-thirds of the MVs in the $\mathrm{H}_{3} \mathrm{R}$ and $\mathrm{H}_{4} \mathrm{R}(70.9 \%$ and $69.4 \%$, respectively) were predicted to be functionally deleterious [5].
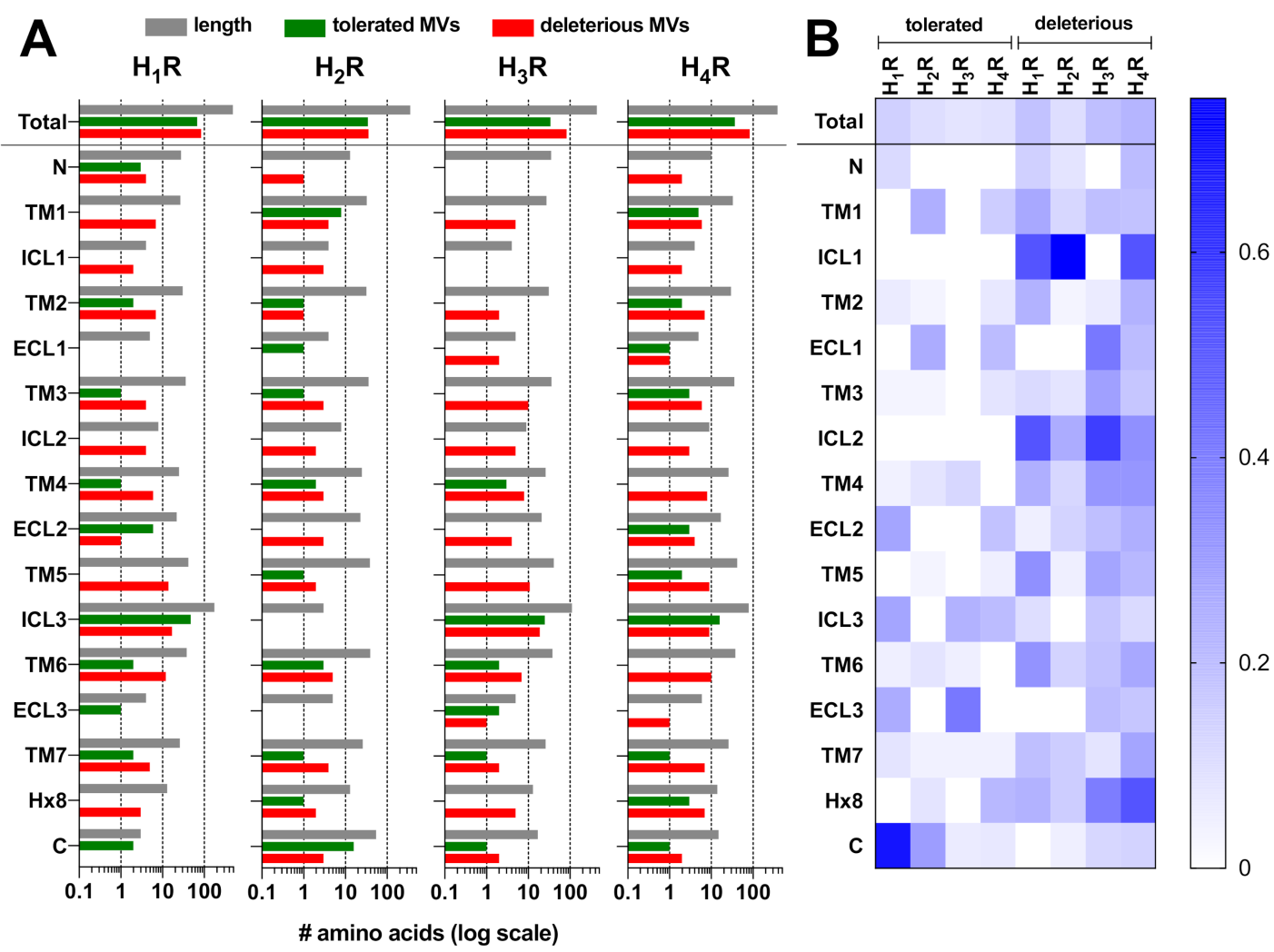

Figure 1. Distribution and predicted impact of 463 genetic missense variants (MVs) in histamine receptor family from nearly 61,000 unrelated individuals. (A) The number of tolerated (sorting intolerant from tolerant, SIFT $>0.05$ and/or PolyPhen $<0.1$ ) and deleterious (SIFT $\leq 0.05$ and/or PolyPhen $\geq 0.1$ ) MVs is plotted in green and red bars, respectively, for the total receptor and for each structural segment. The number of amino acids (length) for each receptor subtype and the individual structural segments is plotted in gray bars. (B) MV density was determined by normalizing the number of MVs for the length (i.e., number of amino acids) of each receptor subtype or indicated structural segment. $\mathrm{N}$ is $\mathrm{N}$-terminal tail, TM is transmembrane, ICL is intracellular loop, ECL is extracellular loop, Hx8 is helix 8, and C is C-terminal tail.

The majority of MVs that are predicted to be tolerated are found in the long intracellular loop (ICL) 3 of $\mathrm{H}_{1} \mathrm{R}$ (48 out of 68 ), $\mathrm{H}_{3} \mathrm{R}$ (25 out of 34 ), and $\mathrm{H}_{4} \mathrm{R}$ (16 out of 37 ), whereas $\mathrm{H}_{2} \mathrm{R}$ contains nearly half of the tolerated MVs (16 out of 35$)$ in its relatively long C-terminal tail (Figure 1A, Supplementary Figure S2), which might be consistent with the unstructured nature of these relatively long intracellular domains. However, the long ICL3s of $\mathrm{H}_{1} \mathrm{R}$, $\mathrm{H}_{3} \mathrm{R}$, and $\mathrm{H}_{4} \mathrm{R}$ (20-36\% of total receptor length) also contain relatively high numbers of potentially deleterious MVs (i.e., 17 out of 86,19 out of 83 , and 9 out of 84 , respectively) in 
comparison to other structural segments (Figure 1A, Supplementary Figure S2). Nonetheless, the majority of deleterious MVs in the histamine receptor family are situated in the transmembrane (TM) and helix 8 domains (i.e., 58 out of 86 for $\mathrm{H}_{1} \mathrm{R} ; 24$ out of 36 for $\mathrm{H}_{2} \mathrm{R}$; 50 out of 83 for $\mathrm{H}_{3} \mathrm{R} ; 60$ out of 84 for $\mathrm{H}_{4} \mathrm{R}$ ), which might not be surprising considering both their size (49-68\% of total $\mathrm{H}_{\mathrm{x}} \mathrm{R}$ length) and role in transducing extracellular ligand-binding into intracellular $\mathrm{G}$ protein signaling via conformational rearrangements. In addition, also the very short ICL1 and ICL2 contain a relatively high-density in deleterious MVs (Figure 1B).

Moreover, nearly half of the deleterious MVs (129 out of 289) in the histamine receptor family affects key functional GPCR motifs, including the extracellular vestibule involved in ligand entry, the ligand-binding sites, the conserved microswitches involved in GPCR (in)activation (i.e., ionic lock motif, NPxxY motif, CWxP motif, PIF motif, and sodium pocket), and the GPCR-G protein/ $\beta$-arrestin interaction interface (Figure 2$)$. Indeed, most tolerated MVs (88.5\%) are mapped outside these key functional motifs (Figure 2).

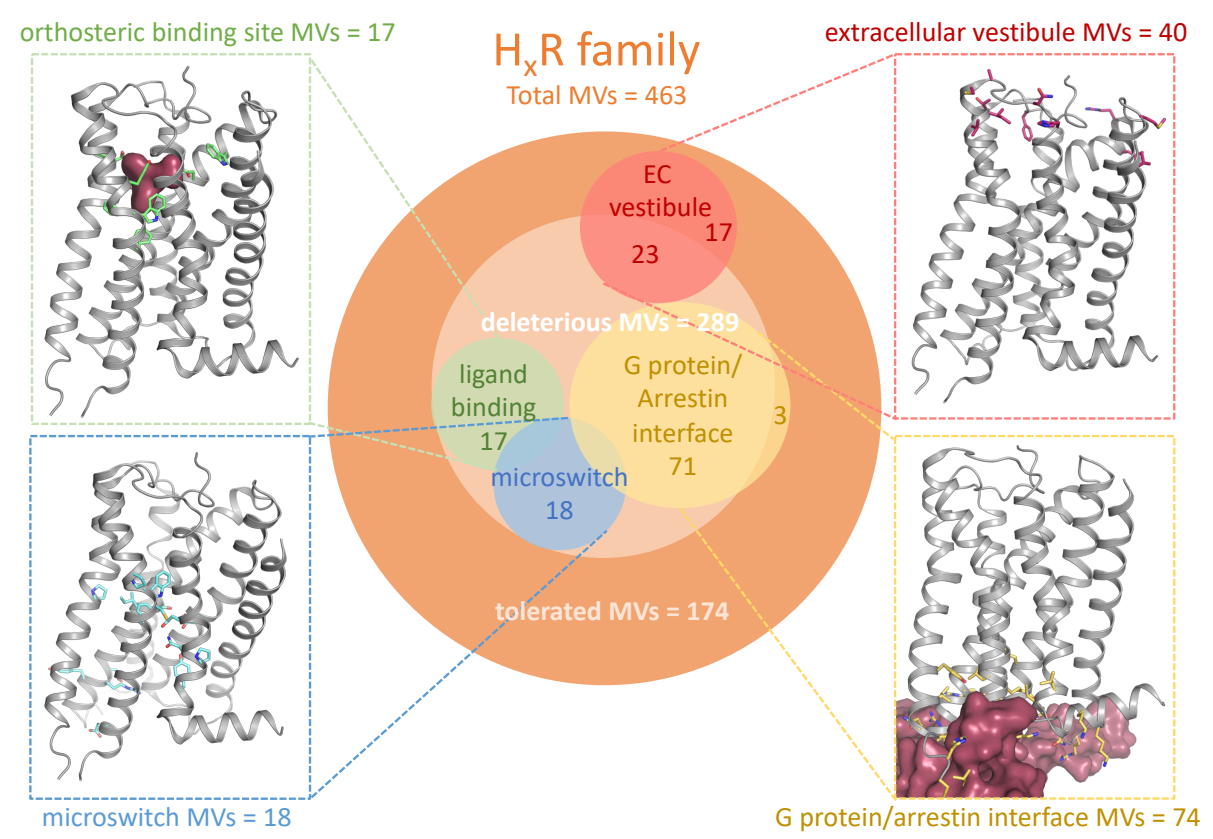

Figure 2. Functional mapping of $463 \mathrm{MVs}$ predicted to be tolerated or deleterious in histamine receptor family from nearly 61,000 unrelated individuals. Tolerated (SIFT $>0.05$ and/or PolyPhen $<0.1$ ) and deleterious (SIFT $\leq 0.05$ and/or PolyPhen $\geq 0.1$ ) MVs were mapped to functional sites that are known to be involved in histamine receptor-ligand binding (i.e., orthosteric binding site; green), ligand entry trajectory (i.e., extracellular vestibule; red), (in)activation (i.e., microswitches, including the allosteric sodium pocket; blue), and the GPCR-G protein/arrestin-binding interface (gold). The displayed $\mathrm{H}_{1} \mathrm{R}$ structures (Protein Data Bank (PDB) code 3RZE) show MVs in the indicated functional sites.

Interestingly, the ExAc dataset reported $\mathrm{E} 410^{6.30 \times 30} \mathrm{~K}$ in the $\mathrm{H}_{1} \mathrm{R}$ as a rare heterozygous MV with a MAF of $3.30 \times 10^{-5}$ that is predicted to be deleterious by its SIFT/PolyPhen score and functionally maps to both a microswitch and the $G$ protein/arrestin interface (Table 2; Figure 3). The ionic lock between $E 410^{6.30 \times 30} \mathrm{~K}$ and the highly conserved $\mathrm{D}(\mathrm{E}) \mathrm{RY}$ motif at the intracellular ends of TM6 and TM3, respectively, in the ground state crystal structure of bovine rhodopsin, has been identified as key interaction to maintain the receptor in an inactive conformation by restricting the distance and orientation between TM3 and TM6 (Figure 3) [13]. Indeed, this distance between TM3 and TM6 is considerably enlarged in the active crystal structure of the $\beta_{2}$-adrenergic receptor as a consequence of a $14 \AA$ outward movement of TM6 (Figure 3) [14]. Importantly, removal of this ionic lock interaction by site-directed mutagenesis increased the constitutive activity of both 
rhodopsin and $\beta_{2}$-adrenergic receptor [15-18], as well as several other GPCRs, including the $\mathrm{H}_{2} \mathrm{R}$ [19]. The ionic lock interaction between $\mathrm{R} 125^{3.50 \times 50}$ and $\mathrm{E} 410^{6.30 \times 30}$ is not observed in the inactive crystal structure of doxepin-bound $\mathrm{H}_{1} \mathrm{R}$ (Figure 3 ), which might be the consequence of substituting ICL3 with the T4-lysozyme for the crystallization process [20]. In fact, this interaction is not always present in crystal structures despite it being proven experimentally [17].

Table 2. ExAC data extracted from the GPCRdb ${ }^{1}$ for the rare, deleterious $\mathrm{H}_{1} \mathrm{R}$ MVs selected in this study.

\begin{tabular}{|c|c|c|c|c|c|c|c|c|c|}
\hline Position & GPCRdb & Segment & Variant & $\begin{array}{c}\text { Allele } \\
\text { Count }^{2}\end{array}$ & $\begin{array}{c}\text { Allele } \\
\text { Number }{ }^{3}\end{array}$ & $\begin{array}{c}\text { Allele } \\
\text { Frequency }\end{array}$ & Homozygotes ${ }^{5}$ & SIFT $^{6}$ & PolyPhen ${ }^{7}$ \\
\hline 127 & $3.52 \times 52$ & TM3 & $\mathrm{R}=>\mathrm{H}$ & 3 & 121266 & $2.47 \times 10^{-5}$ & 0 & 0.02 & 0.909 \\
\hline 139 & $34.57 \times 57$ & ICL2 & $\mathrm{R}=>\mathrm{H}$ & 7 & 121276 & $5.77 \times 10^{-5}$ & 1 & 0 & 1 \\
\hline 409 & $6.29 \times 29$ & TM6 & $\mathrm{R}=>\mathrm{H}$ & 2 & 121228 & $1.65 \times 10^{-5}$ & 0 & 0 & 0.996 \\
\hline 410 & $6.30 \times 30$ & TM6 & $E=>K$ & 4 & 121242 & $3.30 \times 10^{-5}$ & 0 & 0 & 0.996 \\
\hline
\end{tabular}

${ }^{1}$ https://gpcrdb.org/mutational_landscape/protein/hrh1_human/ (accessed on 20 January 2021). ${ }^{2}$ Number of alleles with this variant in ExAC dataset. ${ }^{3}$ Total number of alleles analyzed in ExAC dataset. ${ }^{4}$ Minor allele frequency calculated as alleles with variant/total number of alleles. Frequency $<1 \times 10^{-3}$ is considered rare. ${ }^{5}$ Number of individuals in ExAC dataset with both alleles affected (=homozygotes). ${ }^{6}$ SIFT $\leq 0.05$ is considered deleterious. ${ }^{7}$ PolyPhen $\geq 0.1$ is considered deleterious.
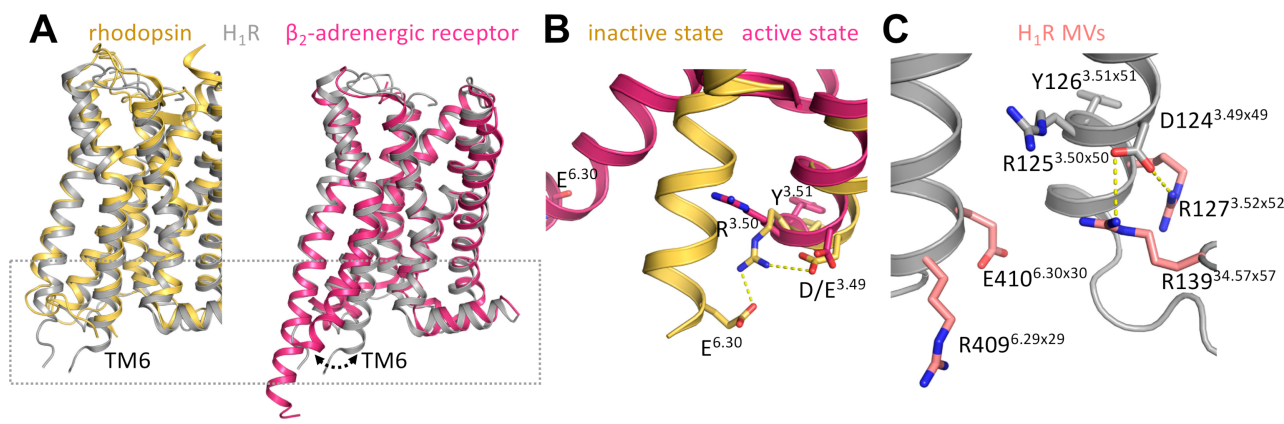

Figure 3. Ionic lock microswitch in inactive and active GPCR structures. (A) Overlay of inactive $\mathrm{H}_{1} \mathrm{R}$ (PDB code 3RZE; gray) on inactive rhodopsin (PDB code 1F88; gold) and active $\beta_{2}$-adrenergic receptor (PDB code 3SN6; magenta) state structures showing the outward movement of TM6 upon receptor activation. (B) The ionic lock between E6.30 and R3.50 of the D(E)RY motif in TM6 and TM3, respectively, in inactive rhodopsin (gold), is broken in the active $\beta_{2}$-adrenergic receptor (magenta) due to the outward movement of TM6. (C) Position of the four amino acid residues (pink) with deleterious MVs in TM3 $\left(\mathrm{R} 127^{3.52 \times 52} \mathrm{H}\right), \mathrm{ICL} 2\left(\mathrm{R} 139^{34.57 \times 57} \mathrm{H}\right)$, and TM6 $\left(\mathrm{R} 6.39 \mathrm{H}\right.$ and $\left.\mathrm{E} 410^{6.30 \times 30} \mathrm{~K}\right)$ of the $\mathrm{H}_{1} \mathrm{R}$ structure.

In addition, the ExAc dataset revealed three arginine to histidine MVs in TM3, ICL2, and TM6 of $\mathrm{H}_{1} \mathrm{R}$ that are predicted to be deleterious by their SIFT/PolyPhen scores and situated in the close vicinity of the putative ionic lock and/or at the predicted GPCR-G protein/arrestin interaction interface (Table 2; Figure 3). $\mathrm{The}_{1} \mathrm{R}$ is known to constitutively activate various $\mathrm{G}_{\mathrm{q}}$ protein-mediated responses, and consequently, earlier identified $\mathrm{H}_{1} \mathrm{R}$ antagonists were found to actually act as inverse agonists [21-23]. We have previously investigated the activation mechanism and constitutive activity of the $\mathrm{H}_{1} \mathrm{R}$ [24-26], and therefore, examined the consequence of these four deleterious $M V s$ on $\mathrm{H}_{1} \mathrm{R}$ function. To this end, we introduced these four MVs individually in the wild-type $H_{1} R$ and evaluated their effect on ligand binding and $\mathrm{G}_{\mathrm{q}}$ protein-mediated signaling.

\subsection{The $E 410^{6.30 \times 30} \mathrm{~K}$ Natural Variant Displays Increased Histamine Affinity}

Initially, the binding characteristics of the four selected natural $\mathrm{hH}_{1} \mathrm{R}$ variants were investigated. Therefore, the various $\mathrm{hH}_{1} \mathrm{R}$ variants were transiently expressed in HEK293T cells and subjected to $\left[{ }^{3} \mathrm{H}\right]$ mepyramine radioligand binding studies. In saturation binding studies, the antagonist radioligand $\left[{ }^{3} \mathrm{H}\right]$ mepyramine displays a similar nanomolar binding affinity for the naturally occurring $\mathrm{hH}_{1} \mathrm{R}$ variants $\mathrm{R} 127^{3.52 \times 52} \mathrm{H}, \mathrm{R} 139^{34.57 \times 57} \mathrm{H}$, $\mathrm{R} 409^{6.29 \times 29} \mathrm{H}$, and $\mathrm{E} 410^{6.30 \times 30} \mathrm{~K}$ as compared to wild-type (WT) $\mathrm{hH}_{1} \mathrm{R}$ (Figure $4 \mathrm{~A}$ and 
Table 3; $p>0.05$, one-way ANOVA with Dunnett's multiple comparisons). Moreover, all variants were also well expressed, as indicated by the high $B_{\max }$ values following $\left[{ }^{3} \mathrm{H}\right]$ mepyramine saturation binding (Table 3). Next, $\left[{ }^{3} \mathrm{H}\right]$ mepyramine competition binding studies were conducted to determine the affinity of the unlabeled antagonists, mepyramine, levocetirizine, and doxepin and the endogenous agonist histamine. The three tested antagonists all have similar binding affinities for all four variants as compared to $\mathrm{WT} \mathrm{hH}_{1} \mathrm{R}$ (Table 4). In contrast, the agonist histamine displays a 6.3-fold increased binding affinity for the $\mathrm{E} 410^{6.30 \times 30} \mathrm{~K}$ variant compared to $\mathrm{WT} \mathrm{hH}_{1} \mathrm{R}$ (Figure 4B; Table 4). A smaller increase in histamine affinity was observed for $\mathrm{R} 127^{3.52 \times 52} \mathrm{H}$ and $\mathrm{R} 139^{34.57 \times 57} \mathrm{H}$ (2.5- and 3.1-fold, respectively), whereas $\mathrm{R} 409^{6.29 \times 29} \mathrm{H}$ has the same affinity as $\mathrm{WT} h \mathrm{H}_{1} \mathrm{R}$.

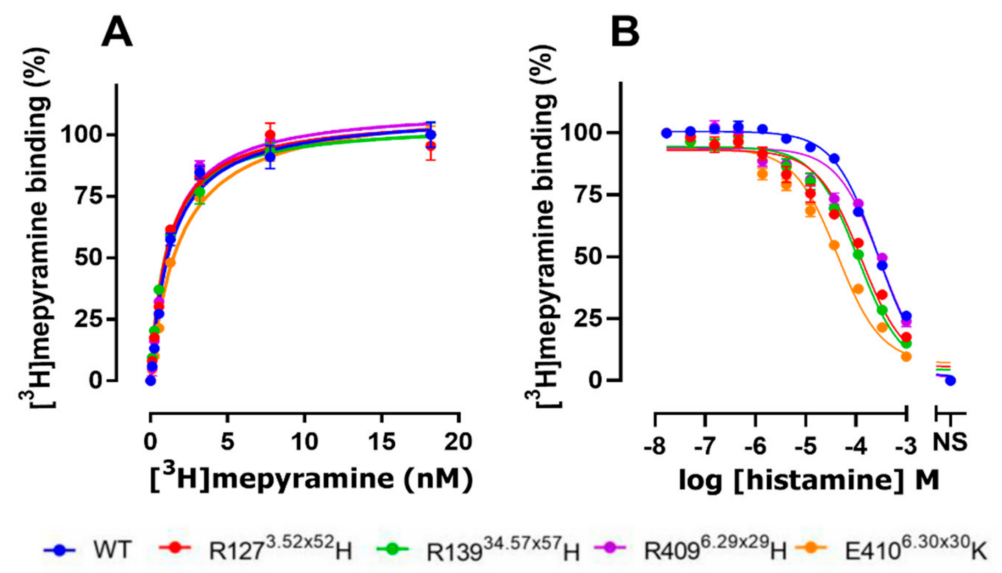

Figure 4. Ligand binding to $\mathrm{hH}_{1} \mathrm{R}$ variants. (A) Specific binding of increasing concentrations $\left[{ }^{3} \mathrm{H}\right]$ mepyramine to HEK293T cell homogenates expressing $\mathrm{hH}_{1} \mathrm{R}$ variants is shown as percentage specific binding of $\left.18 \mathrm{nM} \mathrm{[}{ }^{3} \mathrm{H}\right]$ mepyramine. Data are shown as mean \pm SEM Figure 3. independent experiments performed in duplicate. (B) Competition binding between $7 \mathrm{nM}\left[{ }^{3} \mathrm{H}\right]$ mepyramine and increasing histamine concentrations. Data are shown as mean \pm SEM from 4 independent experiments performed in triplicate. Nonspecific (NS) binding was determined in the presence of $10 \mu \mathrm{M}$ mianserin.

Table 3. Binding affinity $\left(\mathrm{pK}_{\mathrm{d}}\right)$ of $\left[{ }^{3} \mathrm{H}\right]$ mepyramine for $\mathrm{hH}_{1} \mathrm{R}$ variants and their expression levels $\left(B_{\max }\right)$ in HEK293T cells. Data represent the mean \pm standard deviation from 3 independent experiments performed in duplicate.

\begin{tabular}{ccc}
\hline $\mathbf{h H}_{\mathbf{1}} \mathbf{R}$ Variants & $\mathbf{p K}_{\mathbf{d}}$ & $\mathbf{B}_{\mathbf{m a x}}$ (pmol/mg) \\
\hline $\mathrm{WT}$ & $8.9 \pm 0.10$ & $42.5 \pm 12.07$ \\
$\mathrm{R} 127^{3.52 \times 52} \mathrm{H}$ & $8.9 \pm 0.13$ & $35.1 \pm 12.01$ \\
$\mathrm{R} 139^{34.57 \times 57} \mathrm{H}$ & $9.0 \pm 0.06$ & $38.4 \pm 8.42$ \\
$\mathrm{R} 409^{6.29 \times 29} \mathrm{H}$ & $8.9 \pm 0.03$ & $48.4 \pm 12.33$ \\
$\mathrm{E} 410^{6.30 \times 30} \mathrm{~K}$ & $8.7 \pm 0.05$ & $27.8 \pm 7.39$ \\
\hline
\end{tabular}

Table 4. Binding affinity $\left(\mathrm{pK}_{\mathrm{i}}\right)$ of histamine and three representative $\mathrm{H}_{1}$ antagonists for the $\mathrm{hH}_{1} \mathrm{R}$ variants. Data represent the mean \pm standard deviation from at least 3 independent experiments performed in duplicate. Statistical differences $(p<0.05)$ compared to WT were determined using one-way ANOVA with Dunnett's multiple comparison test and are indicated by an asterisk (*).

\begin{tabular}{ccccc}
\hline hH $_{\mathbf{1}} \mathbf{R}$ Variants & Histamine & Mepyramine & Levocetirizine & Doxepin \\
\hline $\mathrm{WT}$ & $4.3 \pm 0.05$ & $8.8 \pm 0.06$ & $7.7 \pm 0.17$ & $9.7 \pm 0.19$ \\
$\mathrm{R} 127^{3.52 \times 52} \mathrm{H}$ & $4.7 \pm 0.02^{*}$ & $8.9 \pm 0.09$ & $7.6 \pm 0.08$ & $9.8 \pm 0.17$ \\
$\mathrm{R} 139^{34.57 \times 57} \mathrm{H}$ & $4.8 \pm 0.03^{*}$ & $8.8 \pm 0.09$ & $7.8 \pm 0.09$ & $9.6 \pm 0.17$ \\
$\mathrm{R} 409^{6.29 \times 29} \mathrm{H}$ & $4.3 \pm 0.09$ & $9.0 \pm 0.33$ & $7.8 \pm 0.17$ & $9.9 \pm 0.29$ \\
$\mathrm{E} 410^{6.30 \times 30} \mathrm{~K}$ & $5.1 \pm 0.10^{*}$ & $8.7 \pm 0.16$ & $7.8 \pm 0.17$ & $9.7 \pm 0.06$ \\
\hline
\end{tabular}




\subsection{The $E 410^{6.30 \times 30} \mathrm{~K}$ Variant Displays Increased Constitutive Activity in G Protein Signaling}

To evaluate the effect of the naturally occurring $R 127^{3.52 \times 52} \mathrm{H}, \mathrm{R} 139^{34.57 \times 57} \mathrm{H}$, $\mathrm{R} 409^{6.29 \times 29} \mathrm{H}$, and $\mathrm{E} 410^{6.30 \times 30} \mathrm{~K}$ variants on $\mathrm{G}$ protein-mediated $\mathrm{hH}_{1} \mathrm{R}$ signaling, we measured $\mathrm{hH}_{1} \mathrm{R}$-mediated NFAT-driven luciferase activity in response to histamine stimulation (Figure $5 \mathrm{~A}$ ). The $\mathrm{E} 410^{6.30 \times 30} \mathrm{~K}$ variant showed increased basal signaling as compared to WT $\mathrm{hH}_{1} \mathrm{R}$ in HEK293T cells transiently transfected with $5 \mathrm{ng}$ receptor-encoding DNA per dish, whereas $\mathrm{R} 127^{3.52 \times 52} \mathrm{H}, \mathrm{R} 139^{34.57 \times 57} \mathrm{H}$, and $\mathrm{R} 409^{6.29 \times 29} \mathrm{H}$ showed reduced constitutive activity (Figure $5 \mathrm{~B}$ ). Histamine induces NFAT reporter gene activity in cells expressing

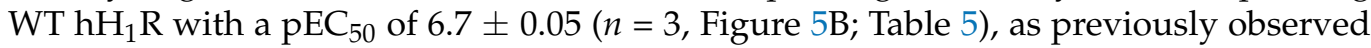
in this reporter gene readout [27]. Histamine has the same potency in cells expressing the $\mathrm{R} 127^{3.52 \times 52} \mathrm{H}, \mathrm{R} 139^{34.57 \times 57} \mathrm{H}$, and $\mathrm{R} 409^{6.29 \times 29} \mathrm{H}$ variants as compared to $\mathrm{WT} h \mathrm{H}_{1} \mathrm{R}$, whereas significantly higher potency ( $0.6 \log$ unit, 4-fold) was observed in cells expressing the $\mathrm{E} 410^{6.30 \times 30} \mathrm{~K}$ variant (Figure $5 \mathrm{~B}$; Table 5).

A

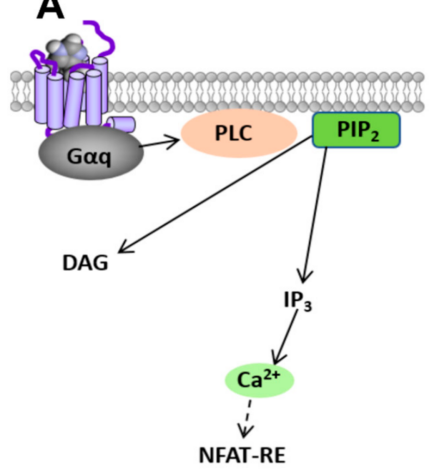

C

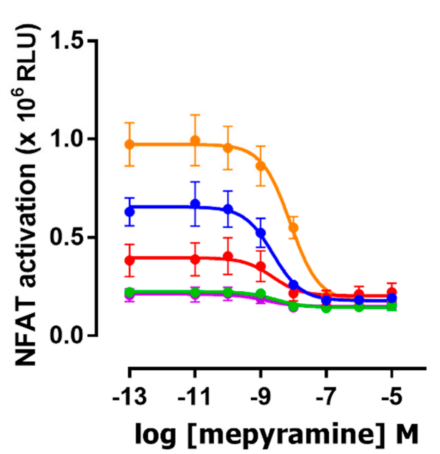

B

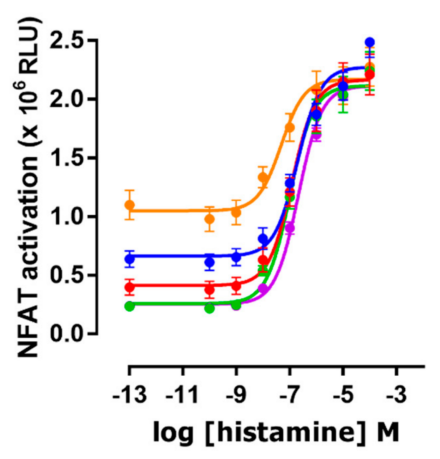

D

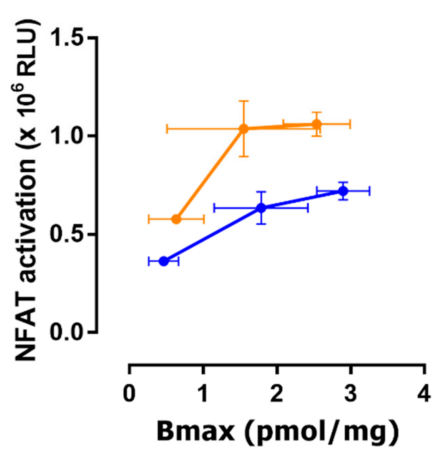

$\rightarrow W T \rightarrow R 127^{3.52 \times 52} \mathrm{H} \rightarrow \mathrm{R} 139^{34.57 \times 57} \mathrm{H} \rightarrow \mathrm{R} 409^{6.29 \times 29} \mathrm{H} \rightarrow \mathrm{E} 410^{6.30 \times 30} \mathrm{~K}$

Figure 5. $\mathrm{G}_{\mathrm{q}}$ protein signaling by $\mathrm{hH}_{1} \mathrm{R}$ variants. (A) $\mathrm{G}_{\mathrm{q}}$-mediated activation of phospholipase $\mathrm{C}$ (PLC) resulting in the cleavage of phosphatidylinositol 4,5-bisphosphate ( $\left.\mathrm{PIP}_{2}\right)$ into diacylglycerol (DAG) and inositol 1,4,5-trisphosphate ( $\left.\mathrm{IP}_{3}\right)$, and the subsequent increase in intracellular $\mathrm{Ca}^{2+}$ levels are measured as NFAT-driven luciferase reporter gene expression (NFAT-RE). (B,C) HEK293T cells co-transfected with $\mathrm{hH}_{1} \mathrm{R}$ variants and NFAT-reporter gene plasmids were incubated with increasing histamine concentrations $(\mathbf{B})$ or inverse agonist mepyramine $(\mathbf{C})$. Data are shown in relative light units (RLU) as mean \pm SEM from 3 independent experiments performed in duplicate. (D) NFAT-driven reporter gene activity in HEK293T cells expressing increasing levels of the constitutively active WT and $\mathrm{E} 4100^{6.30 \times 30} \mathrm{~K} \mathrm{hH}_{1} \mathrm{R}$ variants. Receptor expression was measured by $\left[{ }^{3} \mathrm{H}\right]$ mepyramine binding $\left(B_{\text {max }}\right)$. Data are shown as mean \pm SEM from 4 independent experiments performed in triplicate. 
Table 5. Potency of histamine $\left(\mathrm{pEC}_{50}\right)$ and mepyramine $\left(\mathrm{pIC}_{50}\right)$ to induce or inhibit nuclear factor activated t-cells (NFAT) reporter gene activation, respectively, in HEK293T cells expressing the $\mathrm{hH}_{1} \mathrm{R}$ variants. Data represent the mean \pm standard deviation from 3 independent experiments performed in duplicate. Statistical differences $(p<0.05)$ compared to WT were determined using one-way ANOVA with Dunnett's multiple comparison test and are indicated by an asterisk $\left(^{*}\right)$.

\begin{tabular}{ccc}
\hline hH $\mathbf{1}$ R Variants & Histamine & Mepyramine \\
\hline $\mathrm{WT}$ & $6.7 \pm 0.05$ & $8.7 \pm 0.23$ \\
$\mathrm{R} 127^{3.52 \times 52} \mathrm{H}$ & $6.9 \pm 0.09$ & $8.6 \pm 0.20$ \\
$\mathrm{R} 139^{34.57 \times 57} \mathrm{H}$ & $7.0 \pm 0.06$ & $8.6 \pm 0.13$ \\
$\mathrm{R} 409^{6.29 \times 29} \mathrm{H}$ & $6.7 \pm 0.09$ & $8.8 \pm 0.27$ \\
$\mathrm{E} 410^{6.30 \times 30} \mathrm{~K}$ & $7.3 \pm 0.23^{*}$ & $8.1 \pm 0.22 *$ \\
\hline
\end{tabular}

To confirm the observed effects of these natural variants on the $\mathrm{hH}_{1} \mathrm{R}$ constitutive activity in the NFAT-driven reporter gene assay, transfected HEK293T cells were incubated with the $\mathrm{hH}_{1} \mathrm{R}$ inverse agonist mepyramine [21]. Indeed, mepyramine concentrationdependently inhibited basal signaling of all $\mathrm{hH}_{1} \mathrm{R}$ variants with comparable potencies for $\mathrm{R} 127^{3.52 \times 52} \mathrm{H}, \mathrm{R} 139^{34.57 \times 57} \mathrm{H}, \mathrm{R} 409^{6.29 \times 29} \mathrm{H}$, and $\mathrm{WT} h \mathrm{H}_{1} \mathrm{R}$ (Figure $5 \mathrm{C}$, Table 5). However, mepyramine displays a 4 -fold ( $0.6 \log$ unit) reduced potency to inhibit $\mathrm{E} 410^{6.30 \times 30} \mathrm{~K}$ constitutive signaling to NFAT, as compared to $\mathrm{WT}_{\mathrm{hH}} \mathrm{R}$ (Figure $5 \mathrm{C}$; Table 5). To further confirm that $\mathrm{E} 410^{6.30 \times 30} \mathrm{~K}$ displayed increased constitutive activity as compared to WT, HEK293T cells were co-transfected with the NFAT-driven reporter gene plasmid in combination with 1,5 , and $10 \mathrm{ng}$ of $\mathrm{WT} \mathrm{hH}_{1} \mathrm{R}$ or $\mathrm{E} 410^{6.30 \times 30} \mathrm{~K}$ encoding plasmids. Indeed, at comparable expression $\left(\mathrm{B}_{\text {max }}\right)$ levels, $\mathrm{E} 410^{6.30 \times 30} \mathrm{~K}$ displays a higher level of constitutive activity than WT $\mathrm{hH}_{1} \mathrm{R}$ (Figure 5D).

\section{Discussion}

Despite the increasing accumulation of data on genetic variation in protein-coding sequences in the human population through international consortia, such as the ExAC, a huge gap still exists between the predicted effect of these natural amino acid substitutions based on bioinformatic SIFT and/or PolyPhen scores, and the experimental evaluation of their functional impact on protein function. Recent pharmacogenomic analysis of this ExAC dataset on approved GPCR drug targets revealed that 9522 out of the 14,192 MVs are predicted to be functionally deleterious based on their SIFT or PolyPhen scores, and $1772 \mathrm{MVs}$ involve amino acids in the ligand-binding pocket, conformational microswitches, and $G$ protein/arrestin interaction interface [5].

In this study, we focused this analysis on the four members of the histamine receptor family, showing that 129 predicted deleterious MVs ( $45 \%$ and $28 \%$ of deleterious and total MVs, respectively) are mapped to these functional GPCR domains, and consequently might likely affect histamine receptor function. Indeed, our experimental analysis shows that the $\mathrm{E} 410^{6.30 \times 30} \mathrm{~K}$ MV in the microswitch domain of $\mathrm{H}_{1} \mathrm{R}$ displays increased affinity for the endogenous agonist histamine in combination with increased constitutive activity in $G_{q}$ protein signaling, suggesting that this $H_{1} R$ variant adopts a more active conformational state as compared to $\mathrm{WT} \mathrm{H}_{1} \mathrm{R}$. This indicates that $E 410^{6.30 \times 30}$ in wild-type $\mathrm{H}_{1} \mathrm{R}$ is most likely involved in biasing the conformational ensemble of $\mathrm{H}_{1} \mathrm{R}$ towards the inactive state, probably by forming an ionic lock with the $\mathrm{D}(\mathrm{E}) \mathrm{RY}$ motif in TM3 as reported for several other GPCRs [15-18]. The absence of this ionic lock interaction in the crystal structure of doxepin-bound inactive $\mathrm{H}_{1} \mathrm{R}$ might be the consequence of the replacement of ICL3 with the T4 lysozyme [20], as also observed in other crystal structures of inactive GPCR-T4 lysozyme fusions [28]. Indeed, mutations of E6.30 in other GPCR subtypes are also reported to affect ligand affinity and receptor activity. To illustrate, mutations of this residue to electrostatically neutral or positively-charged residues commonly show increased binding affinity for agonists, as well as an increase in basal activity for a variety of receptors that include the muscarinic acetylcholine $\mathrm{m} 1$ and $\mathrm{m} 2$ receptor $[29,30], \beta_{2}$ adrenergic receptor [17,31], 5-hydroxytryptamine receptor 2A [32], and $\alpha_{1 \mathrm{~B}}$ adrenergic 
receptor [33]. Moreover, natural occurring D6.30 MVs in the follicle-stimulating hormone receptor, luteinizing hormone receptor, and thyroid-stimulating hormone receptor also display increased constitutive receptor activity and are consequently associated with familial spontaneous ovarian hyperstimulation syndrome [34], familial male-limited precocious puberty [35], and hyperfunctioning thyroid adenomas [36], respectively. Interestingly, the ExAC dataset also revealed E229. ${ }^{6.30 \times 30} \mathrm{~K}$ in the $\mathrm{H}_{2} \mathrm{R}$ as a possible deleterious MV. Consequently, the functional effect of this MV might be further investigated in the future, especially since mutation of the DRY motif in the $\mathrm{H}_{2} \mathrm{R}$ has been shown to increase agonist binding affinity, constitutive activity, and structural $\mathrm{H}_{2} \mathrm{R}$ instability [19]. These experimental observations nicely fit with the hypothesis of an ionic lock in the inactive state of the $\mathrm{H}_{2} \mathrm{R}$, and the E229 $9^{6.30 \times 30} \mathrm{~K} \mathrm{MV}$ would, therefore, also expected to increase constitutive $\mathrm{H}_{2} \mathrm{R}$ activity.

The doxepin bound $\mathrm{H}_{1} \mathrm{R}$ structure reveals three positively charged amino acids at an interacting distance to the $\mathrm{D}(\mathrm{E}) \mathrm{RY}$ motif and ionic lock counterpart $\left(\mathrm{E} 410^{6.30 \times 30} \mathrm{~K}\right)$, which have been reported to carry rare, but potentially deleterious MVs [20]. We hypothesized that given the 3D spatial proximity and their charge, these residues most likely are involved in the intricate network of the ionic lock and hence affect receptor pharmacology when mutated. This hypothesis is supported by experimental evidence obtained for other receptors where residues in the proximity to the ionic lock stabilize or destabilize this interaction, such as arginine in the ICL2 of the constitutively active viral GPCR US28, which destabilizes the inactive $\mathrm{D}(\mathrm{E}) \mathrm{RY}$ conformation [37]. Indeed, our experimental analysis shows that MVs R $127^{3.52 \times 52} \mathrm{H}, \mathrm{R} 139^{34.57 \times 57} \mathrm{H}, \mathrm{R} 409^{6.29 \times 29} \mathrm{H}$ reduce receptor-constitutive activity compared to WT. The $\mathrm{R}^{6.29 \times 29}$ is conserved among all 4 histamine receptor subtypes (Supplementary Figure S2), and the $22977^{6.29 \times 29} \mathrm{G}$ MV was identified for the $\mathrm{H}_{4} \mathrm{R}$ in the ExAc dataset. The effect of this $\mathrm{MV}$ on $\mathrm{H}_{4} \mathrm{R}$ constitutive signaling remains to be investigated. Amino acids at positions $3.52 \times 52$ and $34.57 \times 57$ are not conserved between the four histamine subtypes (Supplementary Figure S2).

Although single-nucleotide polymorphisms (SNPs) in histamine receptor genes have been reported in the literature in relation to CNS disorders, inflammation, and cancer, and showing effects of SNPs in the non-coding gene sequences (UTRs and introns), only a few studies have hitherto investigated the impact of MVs in relation to these diseases [38,39]. The impact of $\mathrm{H}_{1} \mathrm{R}$ MVs K19N, D349E (ICL3), Q356H (ICL3), and L449 ${ }^{7.34 \times 33} \mathrm{~S}$ on atypical antipsychotic-induced weight gain was investigated as this is observed in many but not all schizophrenia patients. However, these $4 \mathrm{MVs}$ did not affect olanzapine-induced weight gain in both schizophrenia patients and healthy controls after 6 weeks of treatment [40]. Also, longer treatment periods (2-6 months) with clozapine or olanzapine revealed no association between $\mathrm{H}_{1} \mathrm{R}$ MVs D349E (ICL3) and L449 $9^{7.34 \times 33} \mathrm{~S}$ and weight gain [41,42]. In addition, the L449 $9^{7.34 \times 33}$ S MV could not be associated with Parkinson's disease [43]. The D349A (ICL3) MV did not affect aspirin-induced urticarial/angioedema in a Korean population. Previous analysis of the Ensembl (http:/ /www.ensembl.org (accessed on 20 January 2021)) and NCBI SNPdb (http:/ / www.ncbi.nlm.nih.gov/snp (accessed on 20 January 2021)) databases in a genomic study on the predictive role of $\mathrm{H}_{1} \mathrm{R}$ expression in hematological and solid tumors revealed $84 \mathrm{H}_{1} \mathrm{R}$ MVs among the 2455 available single nucleotide polymorphisms (SNPs) [44]. However, the functional impact of these MVs and their direct association with cancer was not further investigated in this study. To our best knowledge, none of the identified $\mathrm{H}_{2} \mathrm{R}$ and $\mathrm{H}_{4} \mathrm{R}$ MVs have so far been reported to have an impact on diseases. Interestingly, the $\mathrm{H}_{3} \mathrm{R}$ MV A280V (ICL3) was first observed in a patient with Shy-Drager syndrome but later identified as a risk factor for migraine in a Mexican population $[45,46]$. In transfected cells, A280V displayed a reduction in signaling efficacy as compared to wild-type $\mathrm{H}_{3} \mathrm{R}$ without affecting ligand-binding affinities [47].

Hence, these observations highlight the importance of analyzing the genetic variation landscape to better understand receptor function. Our study reveals that missense variations in GPCRs, and specifically in $\mathrm{H}_{1} \mathrm{R}$, predicted to be deleterious occur on residues involved in key microswitches and functional domains, which are indeed likely to affect 
the pharmacology of the receptor. However, this relationship is not often validated. Our analysis shows that the $\mathrm{E} 410^{6.30 \times 30} \mathrm{~K} \mathrm{H}_{1} \mathrm{R}$ variant disrupts the ionic lock microswitch with the $\mathrm{D}(\mathrm{E}) \mathrm{RY}$ motif in TM3 that restrains the $\mathrm{H}_{1} \mathrm{R}$ in a more inactive conformation resulting in increased constitutive activity and histamine affinity. Our results highlight how missense variants can result in receptors that behave pharmacologically different from the wildtype receptor and hence should be considered in the drug discovery process. Moreover, as discussed in detail by Hauser et al., the impact that these genetic variations have on GPCR pharmacology plays a role in human disease directly or indirectly [5]. Directly because genetic variations can induce various degrees of abnormal receptor (de)activation, from pathologically inactive to hyperactive receptors [48,49]. This is illustrated by mutant GPCRs in diseases, such as melanocortin receptors in obesity, extracellular calcium-sensing (CAS) receptor in hypocalcemia, and many others. Furthermore, GPCR genetic variations can also affect human health in an indirect way, as patients might respond differently to therapeutics that target these GPCR variants due to changed receptor pharmacology [5].

\section{Materials and Methods}

\subsection{Materials}

$\left[{ }^{3} \mathrm{H}\right]$ mepyramine (specific activity $20.7 \mathrm{Ci} / \mathrm{mmol}$ ), MicroScint-O scintillation liquid, and GF/C filter plates were bought from PerkinElmer (Waltham, MA, USA). Doxepin, mepyramine maleate, levocetirizine $2 \mathrm{HCl}$ and histamine $\cdot 2 \mathrm{HCl}$ were obtained from SigmaAldrich (St. Louis, MO, USA). NanoGlo ${ }^{\circledR}$ was bought from Promega (Madison, WI, USA). Fetal bovine serum (FBS) was obtained from Bodinco (Alkmaar, The Netherlands), and penicillin/streptomycin was purchased from GE Healthcare (Uppsala, Sweden). FastDigest ${ }^{\mathrm{TM}}$ restriction enzymes, Dulbecco's modified Eagles medium (DMEM), Dulbecco's phosphatebuffered saline (DPBS), trypsin-EDTA, Hanks' balanced salt solution (HBSS), Pierce ${ }^{\mathrm{TM}}$ BCA protein assay kit, GeneJET gel extraction kit and GeneJET plasmid Miniprep kit were bought from Thermo Fisher Scientific (Waltham, MA, USA). $25 \mathrm{kDa}$ linear polyethylenimine (PEI) was purchased from Polysciences (Warrington, PA, USA). The Nluc- $\mathrm{hH}_{1} \mathrm{R} / \mathrm{pcDNA3.1}$ construct was previously reported [50]. The reporter gene construct pNFAT-luc was obtained from Agilent Technologies (Santa Clara, CA, USA). All other reagents were of analytical grade and obtained from conventional commercial sources.

\subsection{Residue Numbering}

To allow systematic comparison of the amino acid residues at different positions in different GPCRs, receptor residue numbers are annotated throughout this study by their Uniprot numbers (for specific receptors only) complemented by their Ballesteros-Weinstein residue number and secondary structure motif in superscript [51,52]. According to the Ballesteros-Weinstein GPCR residue numbering schemes, the most conserved residue in each TM helix is designated X.50. For the most conserved loops, similar residue numbering schemes have been applied. For example, ECL2 residues are labeled 45.X, and the reference residue $C^{45.50}$ is a conserved cysteine forming a disulfide bridge with $C^{3.25}$ in TM3 [53].

\subsection{Genetic Variation Dataset}

Genetic variation data for GPCRs were retrieved from the genetic receptor variants website on GPCRdb (https://gpcrdb.org/mutational_landscape/; accessed on 20 January 2021) [5,8], which compiles GPCR exome sequences from 60706 unrelated humans from 6 distinct populations that were collected by the Exome Aggregation Consortium (ExAC) [4]. The structural segments of the four histamine receptor subtypes that consist of the $\mathrm{N}$ - and C-terminal tail, 7 transmembrane helices, 3 extracellular loops, 3 intracellular loops, and helix8 were assigned based on GPCRdb (https://gpcrdb.org/protein/; accessed on 20 January 2021), as previously described [5,8]. The missense variants (MV) were projected onto each structural segment, and MV density was subsequently calculated by normalizing for the segment length, as previously described [5]. The minor allele frequencies (MAF) of MVs are reported on GPCRdb and represent the allele counts of the 
less frequent allele divided by the total number of alleles at that locus in the ExAC dataset (https://gpcrdb.org/mutational_landscape/; accessed on 20 January 2021) [5,8]. MAF scores $<1 \times 10^{-3}$ and $\geq 1 \times 10^{-3}$ indicate rare and common MVs, respectively. The impact of MVs was classified as functionally tolerated or deleterious by their SIFT and PolyPhen scores that are reported on GPCRdb (https://gpcrdb.org/mutational_landscape/; accessed on 20 January 2021) [5,8]. The SIFT (sorting intolerant from tolerant) scores are from 0-1 with $0-0.05$ being deleterious and $>0.05$ being tolerated [54], whereas PolyPhen scores are from $0-1$ with $0-0.1$ being tolerated and $>0.1$ being deleterious [55].

The tolerated and deleterious MVs in the histamine receptor family were crossmapped with amino acid residue positions that are (putatively) involved in ligand entry (i.e., extracellular vestibule), orthosteric ligand binding, conformational microswitches, and GPCR-G protein/arrestin interaction interface, essentially as previously described [5]. The extracellular vestibule is defined as the amino acid residues in the N-terminal tail, extracellular loops (ECL) 1, 2, and 3. Amino acid positions that align the orthosteric ligand binding site in the histamine receptor family were derived from the doxepin-bound $\mathrm{H}_{1} \mathrm{R}$ crystal structure and site-directed mutagenesis data reported in the mutant browser on GPCRdb (https:/ / gpcrdb.org/mutations/; accessed on 20 January 2021), and consist of: $2.61 \times 60$, $2.66 \times 65,3.28 \times 28,3.32 \times 32,3.33 \times 33,3.36 \times 36,3.37 \times 37,3.40 \times 40,4.51 \times 51$, $4.57 \times 57,4.56 \times 57,5.36 \times 37,5.39 \times 40,5.41 \times 42,5.42 \times 43,5.44 \times 45,5.46 \times 461$, $5.47 \times 47,5.48 \times 48,6.44 \times 44,6.48 \times 48,6.51 \times 51,6.52 \times 52,6.55 \times 55,7.42 \times 41$, and $7.43 \times 42[8,20]$. Reported amino acids positions that are involved in conformational GPCR microswitches include the ionic lock: $3.49 \times 49,3.50 \times 50,3.51 \times 51$, and $6.30 \times 30$; the NPxxY motif: $7.49 \times 49,7.50 \times 50$, and $7.53 \times 53$; the CWxP motif: $6.47 \times 47,6.48 \times 48$, and $6.50 \times 50$; the transmission switch, also known as PIF motif: $3.40 \times 40,5.50 \times 50$, and $6.44 \times 44$; and the allosteric sodium pocket: $2.50 \times 50,3.39 \times 39,6.48 \times 48,7.45 \times 45$, and $7.46 \times 46$ [56-59]. Amino acid positions that putatively form the GPCR-G protein/arrestin interaction interface were assigned based on contacts observed in crystal structures of GPCRs in complex with G protein or arrestin and consist of: $12.48 \times 48,2.36 \times 36$, $2.37 \times 37,2.39 \times 39,2.40 \times 40,3.49 \times 49,3.50 \times 50,3.53 \times 53,3.54 \times 54,3.55 \times 55$, $3.56 \times 56,34.50,34.51 \times 51,34.52 \times 52,34.53 \times 53,34.54 \times 54,34.55 \times 55,34.57 \times 57$, $34.58 \times 58,4.36 \times 36,4.38 \times 38,4.39 \times 39,4.40 \times 40,4.41 \times 41,5.58 \times 58,5.61 \times 61$, $5.64 \times 64,5.65 \times 65,5.67 \times 67,5.68 \times 68,5.69 \times 69,5.71 \times 71,5.72 \times 72,5.74 \times 74$, $5.75 \times 75,5.76 \times 76,6.22 \times 22,6.23 \times 23,6.24 \times 24,6.25 \times 25,6.26 \times 26,6.28 \times 28$, $6.29 \times 29,6.30 \times 30,6.32 \times 32,6.33 \times 33,6.36 \times 36,6.37 \times 37,6.40 \times 40,7.55 \times 55,7.56 \times 56$, $8.47 \times 47,8.48 \times 48,8.49 \times 49,8.51 \times 51$, and $8.52 \times 52[8,60-64]$.

\subsection{Generation of $\mathrm{H}_{1} \mathrm{R}$ Variants}

The $\mathrm{hH}_{1} \mathrm{R}$ variants $\mathrm{R} 127^{3.52 \times 52} \mathrm{H}, \mathrm{R} 139^{34.57 \times 57} \mathrm{H}, \mathrm{R} 409^{6.29 \times 29} \mathrm{H}$, and $\mathrm{E} 410^{6.30 \times 30} \mathrm{~K}$, were created by PCR-based mutagenesis using wild-type $\mathrm{hH}_{1} \mathrm{R}$ (GenBank: NM_00861) as template [65]. The PCR fragments were subcloned into Nluc-hH $\mathrm{H}_{1} \mathrm{R} / \mathrm{pcDNA3.1}$ plasmid using the internal restriction sites PfIMI and EcoRI, and subsequently sequence verified at Eurofins Genomics (Ebersberg, Germany).

\subsection{Cell Culture and Transfection}

HEK293T cells (ATCC; Manassas, VA, USA) were maintained at $37{ }^{\circ} \mathrm{C}, 5 \% \mathrm{CO}_{2}$ in culture medium (Dulbecco's modified Eagle's medium (DMEM) supplemented with 10\% FBS and 1\% penicillin/streptomycin). Transfections of HEK293T cells were performed using the PEI method, as previously described [27]. Briefly, $2 \times 10^{6} \mathrm{HEK} 293 \mathrm{~T}$ cells were seeded in a $10 \mathrm{~cm}$ dish. The next day, $5 \mu \mathrm{g}$ DNA plasmid is mixed by vortexing with $20 \mu \mathrm{g}$ of linear PEI (1:4 ratio) in $150 \mathrm{mM} \mathrm{NaCl}$ solution and incubated for $30 \mathrm{~min}$ at room temperature. Empty pcDEF3 plasmid was used to keep total DNA equal. The transfection mix is gently resuspended and added dropwise to one dish with cells containing $6 \mathrm{~mL}$ fresh medium after incubation. 


\subsection{Radioligand Binding Experiments}

HEK293T cells were collected two days after transfection with $1 \mu \mathrm{g}$ of Nluc-hH $\mathrm{H}_{1} \mathrm{R}$ variant-encoding plasmids per dish and homogenized in binding buffer $\left(50 \mathrm{mM} \mathrm{Na}_{2} \mathrm{HPO}_{4}\right.$ / $\mathrm{KH}_{2} \mathrm{PO}_{4}, \mathrm{pH}$ 7.4) as previously described [27]. For saturation binding assay, cell homogenates were incubated with increasing concentrations of $\left[{ }^{3} \mathrm{H}\right]$ mepyramine $(0-20 \mathrm{nM})$ for 1 hour at $25^{\circ} \mathrm{C}$ with gentle agitation in the absence or presence of $10 \mu \mathrm{M}$ mianserin to detect total and nonspecific binding, respectively. For competition binding assay, cell homogenates were incubated with $7 \mathrm{nM}\left[{ }^{3} \mathrm{H}\right]$ mepyramine in combination with increasing concentrations of unlabeled histamine, doxepin, mepyramine, or levocetirizine, for 1 hour at $25{ }^{\circ} \mathrm{C}$ with gentle agitation. Incubations were stopped by rapid filtration with ice-cold wash buffer (50 mM Tris- $\mathrm{HCl}, \mathrm{pH} 7.4)$ over a $0.5 \%$ polyethyleneimine-coated 96-well GF/C filter plate using a 96-well FilterMate-harvester (Perkin-Elmer; Waltham, MA, USA). The GF/C filter plates were dried, and filter-bound radioactivity was quantified after the addition of $25 \mu \mathrm{L} /$ well MicroScint-O using a Wallac 1450 MicroBeta Trilux counter (PerkinElmer). The binding affinity $\left(\mathrm{K}_{\mathrm{d}}\right)$ of $\left[{ }^{3} \mathrm{H}\right]$ mepyramine and the total number of receptors $\left(\mathrm{B}_{\max }\right)$ were determined using the "One site-Total and nonspecific binding" model in GraphPad Prism 8.4.3. The protein content of the cell homogenates was measured by the BCA kit. Competition binding curves were fitted using the "one-site-Fit logIC50" model in GraphPad Prism 8.4.3, and binding affinities $\left(\mathrm{K}_{\mathrm{i}}\right)$ of unlabeled ligands were subsequently calculated using the Cheng-Prusoff equation:

$$
K_{i}=\frac{I C_{50}}{1+\frac{[L]}{K_{d}}}
$$

where $[L]$ and $K_{d}$ are the concentration and binding affinity of $\left[{ }^{3} \mathrm{H}\right]$ mepyramine, respectively.

\subsection{Nuclear Factor Activated T-Cells (NFAT)-Driven Reporter Gene Assay}

HEK293T cells were transiently co-transfected with $5 \mathrm{ng}$ Nluc-hH $\mathrm{H}_{1} \mathrm{R}$ variants and $2.5 \mu \mathrm{g}$ NFAT-Luc reporter gene plasmids per dish and transferred (50,000 cells/well) into poly-L-lysine-coated white 96-well plates after $24 \mathrm{~h}$, as previously described [27]. The cells were stimulated the next day with histamine for 6 hours to detect agonism, whereas mepyramine was added directly after transferring the cells into the 96-well plates to detect inverse agonism. The incubations were terminated by replacing the medium with $25 \mu \mathrm{L}$ of luciferase assay reagent $(0.83 \mathrm{mM}$ ATP, $0.83 \mathrm{mM}$ d-luciferin, $18.7 \mathrm{mM} \mathrm{MgCl}$, $0.78 \mu \mathrm{M} \mathrm{Na}_{2} \mathrm{HPO}_{4}, 38.9 \mathrm{mM}$ Tris (pH 7.8), 0.39\% (v/v) glycerol, $0.03 \%(v / v)$ Triton X-100, and $2.6 \mu \mathrm{M}$ dithiothreitol). Luminescence was measured ( $1 \mathrm{~s} /$ well) after another $30 \mathrm{~min}$ incubation at $37^{\circ} \mathrm{C}$ in a Mithras LB940 multimode microplate reader (Berthold, Germany). Concentration-response curves were fitted using the "log (agonist) vs. response (three parameters)" model in GraphPad Prism 8.4.3.

\subsection{Data Analysis}

GraphPad Prism version 8.4.3 (GraphPad Software, San Diego, CA, USA) was used for nonlinear regression and statistics.

Supplementary Materials: The following are available online at https:/ /www.mdpi.com/article/10 .3390 /ijms22073702/s1, Figure S1: Frequency and distribution of MVs in histamine receptor family. The number of rare and common MVs was determined for the four histamine receptor subtypes, and their structural segments rare, and common MVs were determined by their reported minor allele frequency scores of $<1 \times 10^{-3}$ and $\geq 1 \times 10^{-3}$, respectively. Figure S2: Location of missense variants in the histamine receptor family. Snake plots for the $\mathrm{H}_{1} \mathrm{R}, \mathrm{H}_{2} \mathrm{R}, \mathrm{H}_{3} \mathrm{R}$, and $\mathrm{H}_{4} \mathrm{R}$ were extracted from GPCRdb and tolerated, and deleterious MVs as predicted by SIFT/PolyPhen analyses are highlighted in green and red, respectively. 
Author Contributions: Conceptualization, R.L. and H.F.V.; methodology, X.M. and M.A.S.; software, M.A.S.; validation, X.M.; formal analysis, X.M., M.A.S. and H.F.V.; investigation, X.M. and M.A.S.; resources, B.Z., R.L., and H.F.V.; data curation, X.M. and M.A.S.; writing-original draft preparation, X.M., M.A.S. and H.F.V.; writing—review and editing, B.Z., R.L. and H.F.V.; visualization, X.M., M.A.S. and H.F.V.; supervision, R.L., H.F.V. and B.Z.; project administration, R.L. and H.F.V.; funding acquisition, X.M. All authors have read and agreed to the published version of the manuscript.

Funding: X.M. is supported by a CSC Chinese scholarship grant (201703250074).

Institutional Review Board Statement: Not applicable.

Informed Consent Statement: Not applicable.

Data Availability Statement: Not applicable.

Conflicts of Interest: The authors declare no conflict of interest.

\section{References}

1. Almén, M.S.; Nordström, K.J.V.; Fredriksson, R.; Schiöth, H.B. Mapping the human membrane proteome: A majority of the human membrane proteins can be classified according to function and evolutionary origin. BMC Biol. 2009, 7, 50. [CrossRef]

2. Sriram, K.; Insel, P.A. G Protein-Coupled Receptors as Targets for Approved Drugs: How Many Targets and How Many Drugs? Mol. Pharmacol. 2018, 93, 251-258. [CrossRef]

3. Hauser, A.S.; Attwood, M.M.; Rask-Andersen, M.; Schiöth, H.B.; Gloriam, D.E. Trends in GPCR drug discovery: New agents, targets and indications. Nat. Rev. Drug Discov. 2017, 16, 829-842. [CrossRef]

4. $\quad$ Lek, M.; Karczewski, K.J.; Minikel, E.V.; Samocha, K.E.; Banks, E.; Fennell, T.; O’Donnell-Luria, A.H.; Ware, J.S.; Hill, A.J.; Cummings, B.B.; et al. Exome Aggregation Consortium Analysis of protein-coding genetic variation in 60,706 humans. Nature 2016, 536, 285-291. [CrossRef]

5. Hauser, A.S.; Chavali, S.; Masuho, I.; Jahn, L.J.; Martemyanov, K.A.; Gloriam, D.E.; Babu, M.M. Pharmacogenomics of GPCR Drug Targets. Cell 2018, 172, 41-54.e19. [CrossRef]

6. Panula, P.; Chazot, P.L.; Cowart, M.; Gutzmer, R.; Leurs, R.; Liu, W.L.S.; Stark, H.; Thurmond, R.L.; Haas, H.L. International Union of Basic and Clinical Pharmacology. XCVIII. Histamine Receptors. Pharmacol. Rev. 2015, 67, 601-655. [CrossRef]

7. Tiligada, E.; Ennis, M. Histamine pharmacology: From Sir Henry Dale to the 21st century. Br. J. Pharmacol. 2020, 177, 469-489. [CrossRef] [PubMed]

8. Kooistra, A.J.; Mordalski, S.; Pándy-Szekeres, G.; Esguerra, M.; Mamyrbekov, A.; Munk, C.; Keserü, G.M.; Gloriam, D.E. GPCRdb in 2021: Integrating GPCR sequence, structure and function. Nucleic Acids Res. 2021, 49, D335-D343. [CrossRef]

9. Łażewska, D.; Kieć-Kononowicz, K. Progress in the development of histamine H3 receptor antagonists/inverse agonists: A patent review (2013-2017). Expert Opin. Ther. Pat. 2018, 28, 175-196. [CrossRef]

10. Syed, Y.Y. Pitolisant: First Global Approval. Drugs 2016, 76, 1313-1318. [CrossRef]

11. Urquhart, L. FDA new drug approvals in Q3 2019. Nat. Rev. Drug Discov. 2019, 18, 816. [CrossRef]

12. Thurmond, R.L.; Venable, J.; Savall, B.; La, D.; Snook, S.; Dunford, P.J.; Edwards, J.P. Clinical Development of Histamine H4 Receptor Antagonists. Handb. Exp. Pharmacol. 2017, 241, 301-320. [PubMed]

13. Palczewski, K.; Kumasaka, T.; Hori, T.; Behnke, C.A.; Motoshima, H.; Fox, B.A.; Le Trong, I.; Teller, D.C.; Okada, T.; Stenkamp, R.E.; et al. Crystal structure of rhodopsin: A G protein-coupled receptor. Science 2000, 289, 739-745. [CrossRef] [PubMed]

14. Rasmussen, S.G.F.; Devree, B.T.; Zou, Y.; Kruse, A.C.; Chung, K.Y.; Kobilka, T.S.; Thian, F.S.; Chae, P.S.; Pardon, E.; Calinski, D.; et al. Crystal structure of the $\beta(2)$ adrenergic receptor-Gs protein complex. Nature 2011, 477, 549-555. [CrossRef]

15. Kim, J.M.; Altenbach, C.; Thurmond, R.L.; Khorana, H.G.; Hubbell, W.L. Structure and function in rhodopsin: Rhodopsin mutants with a neutral amino acid at E134 have a partially activated conformation in the dark state. Proc. Natl. Acad. Sci. USA 1997, 94, 14273-14278. [CrossRef]

16. Ramon, E.; Cordomi, A.; Bosch, L.; Zernii, E.Y.; Senin, I.I.; Manyosa, J.; Philippov, P.P.; Pérez, J.J.; Garriga, P. Critical role of electrostatic interactions of amino acids at the cytoplasmic region of helices 3 and 6 in rhodopsin conformational properties and activation. J. Biol. Chem. 2007, 282, 14272-14282. [CrossRef] [PubMed]

17. Ballesteros, J.A.; Jensen, A.D.; Liapakis, G.; Rasmussen, S.G.; Shi, L.; Gether, U.; Javitch, J.A. Activation of the beta 2-adrenergic receptor involves disruption of an ionic lock between the cytoplasmic ends of transmembrane segments 3 and 6 . J. Biol. Chem. 2001, 276, 29171-29177. [CrossRef]

18. Valentin-Hansen, L.; Groenen, M.; Nygaard, R.; Frimurer, T.M.; Holliday, N.D.; Schwartz, T.W. The arginine of the DRY motif in transmembrane segment III functions as a balancing micro-switch in the activation of the $\beta 2$-adrenergic receptor. J. Biol. Chem. 2012, 287, 31973-31982. [CrossRef]

19. Alewijnse, A.E.; Timmerman, H.; Jacobs, E.H.; Smit, M.J.; Roovers, E.; Cotecchia, S.; Leurs, R. The effect of mutations in the DRY motif on the constitutive activity and structural instability of the histamine $\mathrm{H}(2)$ receptor. Mol. Pharmacol. 2000, 57, 890-898.

20. Shimamura, T.; Shiroishi, M.; Weyand, S.; Tsujimoto, H.; Winter, G.; Katritch, V.; Abagyan, R.; Cherezov, V.; Liu, W.; Han, G.W.; et al. Structure of the human histamine H1 receptor complex with doxepin. Nature 2011, 475, 65-70. [CrossRef] 
21. Bakker, R.A.; Wieland, K.; Timmerman, H.; Leurs, R. Constitutive activity of the histamine H(1) receptor reveals inverse agonism of histamine H(1) receptor antagonists. Eur. J. Pharmacol. 2000, 387, R5-R7. [CrossRef]

22. Bakker, R.A.; Schoonus, S.B.; Smit, M.J.; Timmerman, H.; Leurs, R. Histamine H(1)-receptor activation of nuclear factor-kappa B: Roles for $\mathrm{G}$ beta gamma- and G alpha(q/11)-subunits in constitutive and agonist-mediated signaling. Mol. Pharmacol. 2001, 60, 1133-1142. [CrossRef] [PubMed]

23. Yu, N.; Atienza, J.M.; Bernard, J.; Blanc, S.; Zhu, J.; Wang, X.; Xu, X.; Abassi, Y.A. Real-time monitoring of morphological changes in living cells by electronic cell sensor arrays: An approach to study G protein-coupled receptors. Anal. Chem. 2006, 78, 35-43. [CrossRef] [PubMed]

24. Jongejan, A.; Bruysters, M.; Ballesteros, J.A.; Haaksma, E.; Bakker, R.A.; Pardo, L.; Leurs, R. Linking agonist binding to histamine H1 receptor activation. Nat. Chem. Biol. 2005, 1, 98-103. [CrossRef]

25. Bakker, R.A.; Jongejan, A.; Sansuk, K.; Hacksell, U.; Timmerman, H.; Brann, M.R.; Weiner, D.M.; Pardo, L.; Leurs, R. Constitutively active mutants of the histamine $\mathrm{H} 1$ receptor suggest a conserved hydrophobic asparagine-cage that constrains the activation of class A G protein-coupled receptors. Mol. Pharmacol. 2008, 73, 94-103. [CrossRef] [PubMed]

26. Sansuk, K.; Deupi, X.; Torrecillas, I.R.; Jongejan, A.; Nijmeijer, S.; Bakker, R.A.; Pardo, L.; Leurs, R. A structural insight into the reorientation of transmembrane domains 3 and 5 during family A G protein-coupled receptor activation. Mol. Pharmacol. 2011, 79, 262-269. [CrossRef]

27. Bosma, R.; Moritani, R.; Leurs, R.; Vischer, H.F. BRET-based $\beta$-arrestin2 recruitment to the histamine H1 receptor for investigating antihistamine binding kinetics. Pharmacol. Res. 2016, 111, 679-687. [CrossRef]

28. Rosenbaum, D.M.; Rasmussen, S.G.F.; Kobilka, B.K. The structure and function of G-protein-coupled receptors. Nature 2009, 459, 356-363. [CrossRef]

29. Högger, P.; Shockley, M.S.; Lameh, J.; Sadée, W. Activating and inactivating mutations in N- and C-terminal i3 loop junctions of muscarinic acetylcholine Hm1 receptors. J. Biol. Chem. 1995, 270, 7405-7410. [CrossRef]

30. Leppik, R.A.; Miller, R.C.; Eck, M.; Paquet, J.L. Role of acidic amino acids in the allosteric modulation by gallamine of antagonist binding at the $\mathrm{m} 2$ muscarinic acetylcholine receptor. Mol. Pharmacol. 1994, 45, 983-990. [PubMed]

31. Ghanouni, P.; Schambye, H.; Seifert, R.; Lee, T.W.; Rasmussen, S.G.; Gether, U.; Kobilka, B.K. The effect of pH on beta(2) adrenoceptor function. Evidence for protonation-dependent activation. J. Biol. Chem. 2000, 275, 3121-3127. [CrossRef]

32. Shapiro, D.A.; Kristiansen, K.; Weiner, D.M.; Kroeze, W.K.; Roth, B.L. Evidence for a model of agonist-induced activation of 5-hydroxytryptamine 2A serotonin receptors that involves the disruption of a strong ionic interaction between helices 3 and 6 . J. Biol. Chem. 2002, 277, 11441-11449. [CrossRef]

33. Greasley, P.J.; Fanelli, F.; Rossier, O.; Abuin, L.; Cotecchia, S. Mutagenesis and modelling of the alpha(1b)-adrenergic receptor highlight the role of the helix 3/helix 6 interface in receptor activation. Mol. Pharmacol. 2002, 61, 1025-1032. [CrossRef]

34. Montanelli, L.; Delbaere, A.; Di Carlo, C.; Nappi, C.; Smits, G.; Vassart, G.; Costagliola, S. A mutation in the follicle-stimulating hormone receptor as a cause of familial spontaneous ovarian hyperstimulation syndrome. J. Clin. Endocrinol. Metab. 2004, 89, 1255-1258. [CrossRef]

35. Laue, L.; Chan, W.Y.; Hsueh, A.J.; Kudo, M.; Hsu, S.Y.; Wu, S.M.; Blomberg, L.; Cutler, G.B. Genetic heterogeneity of constitutively activating mutations of the human luteinizing hormone receptor in familial male-limited precocious puberty. Proc. Natl. Acad. Sci. USA 1995, 92, 1906-1910. [CrossRef]

36. Parma, J.; Duprez, L.; Van Sande, J.; Cochaux, P.; Gervy, C.; Mockel, J.; Dumont, J.; Vassart, G. Somatic mutations in the thyrotropin receptor gene cause hyperfunctioning thyroid adenomas. Nature 1993, 365, 649-651. [CrossRef]

37. Burg, J.S.; Ingram, J.R.; Venkatakrishnan, A.J.; Jude, K.M.; Dukkipati, A.; Feinberg, E.N.; Angelini, A.; Waghray, D.; Dror, R.O.; Ploegh, H.L.; et al. Structural biology. Structural basis for chemokine recognition and activation of a viral G protein-coupled receptor. Science 2015, 347, 1113-1117. [CrossRef]

38. Micallef, S.; Sasse, A. Genetic Polymorphisms in the Histamine Receptor Family. In Histamine Receptors; Blandina, P., Passani, M.B., Eds.; Preclinical and Clinical Aspects; Humana: Cham, Switzerland, 2016; Volume 28, pp. 51-74.

39. García-Martín, E.; Ayuso, P.; Martínez, C.; Blanca, M.; Agúndez, J.A.G. Histamine pharmacogenomics. Pharmacogenomics 2009, 10, 867-883. [CrossRef]

40. Godlewska, B.R.; Olajossy-Hilkesberger, L.; Olajossy, M.; Limon, J.; Landowski, J. Polymorphisms of the histamine receptor (H1HR) gene are not associated with olanzapine-induced weight gain. J. Clin. Psychopharmacol. 2013, 33, 436-437. [CrossRef] [PubMed]

41. Hong, C.-J.; Lin, C.-H.; Yu, Y.W.-Y.; Chang, S.-C.; Wang, S.-Y.; Tsai, S.-J. Genetic variant of the histamine-1 receptor (glu349asp) and body weight change during clozapine treatment. Psychiatr. Genet. 2002, 12, 169-171. [CrossRef] [PubMed]

42. Ujike, H.; Nomura, A.; Morita, Y.; Morio, A.; Okahisa, Y.; Kotaka, T.; Kodama, M.; Ishihara, T.; Kuroda, S. Multiple genetic factors in olanzapine-induced weight gain in schizophrenia patients: A cohort study. J. Clin. Psychiatry 2008, 69, 1416-1422. [CrossRef] [PubMed]

43. García-Martín, E.; Ayuso, P.; Luengo, A.; Martínez, C.; Agúndez, J.A. Genetic variability of histamine receptors in patients with Parkinson's disease. BMC Med. Genet. 2008, 9, 15. [CrossRef] [PubMed]

44. Wang, M.; Wei, X.; Shi, L.; Chen, B.; Zhao, G.; Yang, H. Integrative genomic analyses of the histamine H1 receptor and its role in cancer prediction. Int. J. Mol. Med. 2014, 33, 1019-1026. [CrossRef] 
45. Millán-Guerrero, R.O.; Baltazar-Rodríguez, L.M.; Cárdenas-Rojas, M.I.; Ramírez-Flores, M.; Isais-Millán, S.; Delgado-Enciso, I.; Caballero-Hoyos, R.; Trujillo-Hernández, B. A280V polymorphism in the histamine H3 receptor as a risk factor for migraine. Arch. Med. Res. 2011, 42, 44-47. [CrossRef] [PubMed]

46. Wiedemann, P.; Bönisch, H.; Oerters, F.; Brüss, M. Structure of the human histamine H3 receptor gene (HRH3) and identification of naturally occurring variations. J. Neural Transm. 2002, 109, 443-453. [CrossRef] [PubMed]

47. Flores-Clemente, C.; Osorio-Espinoza, A.; Escamilla-Sánchez, J.; Leurs, R.; Arias, J.-M.; Arias-Montaño, J.-A. A single-point mutation (Ala280Val) in the third intracellular loop alters the signalling properties of the human histamine H3 receptor stably expressed in CHO-K1 cells. Br. J. Pharmacol. 2013, 170, 127-135. [CrossRef]

48. Schöneberg, T.; Liebscher, I. Mutations in G Protein-Coupled Receptors: Mechanisms, Pathophysiology and Potential Therapeutic Approaches. Pharmacol. Rev. 2021, 73, 89-119. [CrossRef]

49. Smit, M.J.; Vischer, H.F.; Bakker, R.A.; Jongejan, A.; Timmerman, H.; Pardo, L.; Leurs, R. Pharmacogenomic and structural analysis of constitutive g protein-coupled receptor activity. Annu. Rev. Pharmacol. Toxicol. 2007, 47, 53-87. [CrossRef]

50. Stoddart, L.A.; Vernall, A.J.; Bouzo-Lorenzo, M.; Bosma, R.; Kooistra, A.J.; de Graaf, C.; Vischer, H.F.; Leurs, R.; Briddon, S.J.; Kellam, B.; et al. Development of novel fluorescent histamine H1-receptor antagonists to study ligand-binding kinetics in living cells. Sci. Rep. 2018, 8, 1572. [CrossRef]

51. Ballesteros, J.A.; Weinstein, H. Integrated methods for the construction of three-dimensional models and computational probing of structure-function relations in G protein-coupled receptors. Methods Neurosci. 1995, 25, 366-428.

52. Isberg, V.; de Graaf, C.; Bortolato, A.; Cherezov, V.; Katritch, V.; Marshall, F.H.; Mordalski, S.; Pin, J.-P.; Stevens, R.C.; Vriend, G.; et al. Generic GPCR residue numbers-Aligning topology maps while minding the gaps. Trends Pharmacol. Sci. 2015, 36, 22-31. [CrossRef] [PubMed]

53. De Graaf, C.; Foata, N.; Engkvist, O.; Rognan, D. Molecular modeling of the second extracellular loop of G-protein coupled receptors and its implication on structure-based virtual screening. Proteins 2008, 71, 599-620. [CrossRef]

54. Ng, P.C.; Henikoff, S. SIFT: Predicting amino acid changes that affect protein function. Nucleic Acids Res. 2003, 31, 3812-3814. [CrossRef] [PubMed]

55. Adzhubei, I.; Jordan, D.M.; Sunyaev, S.R. Predicting functional effect of human missense mutations using PolyPhen-2. Curr. Protoc. Hum. Genet. 2013, 76, 7-20. [CrossRef] [PubMed]

56. Trzaskowski, B.; Latek, D.; Yuan, S.; Ghoshdastider, U.; Debinski, A.; Filipek, S. Action of molecular switches in GPCRsTheoretical and experimental studies. Curr. Med. Chem. 2012, 19, 1090-1109. [CrossRef] [PubMed]

57. Wacker, D.; Wang, C.; Katritch, V.; Han, G.W.; Huang, X.-P.; Vardy, E.; McCorvy, J.D.; Jiang, Y.; Chu, M.; Siu, F.Y.; et al. Structural features for functional selectivity at serotonin receptors. Science 2013, 340, 615-619. [CrossRef]

58. Venkatakrishnan, A.J.; Deupi, X.; Lebon, G.; Heydenreich, F.M.; Flock, T.; Miljus, T.; Balaji, S.; Bouvier, M.; Veprintsev, D.B.; Tate, C.G.; et al. Diverse activation pathways in class A GPCRs converge near the G-protein-coupling region. Nature 2016, 536, 484-487. [CrossRef]

59. Zarzycka, B.; Zaidi, S.A.; Roth, B.L.; Katritch, V. Harnessing ion-binding sites for GPCR pharmacology. Pharmacol. Rev. 2019, 71, 571-595. [CrossRef] [PubMed]

60. Flock, T.; Hauser, A.S.; Lund, N.; Gloriam, D.E.; Balaji, S.; Babu, M.M. Selectivity determinants of GPCR-G-protein binding. Nature 2017, 545, 317-322. [CrossRef]

61. Lee, Y.; Warne, T.; Nehmé, R.; Pandey, S.; Dwivedi-Agnihotri, H.; Chaturvedi, M.; Edwards, P.C.; García-Nafría, J.; Leslie, A.G.W.; Shukla, A.K.; et al. Molecular basis of $\beta$-arrestin coupling to formoterol-bound $\beta 1$-adrenoceptor. Nature 2020, 159, $1022-1025$. [CrossRef]

62. Staus, D.P.; Hu, H.; Robertson, M.J.; Kleinhenz, A.L.W.; Wingler, L.M.; Capel, W.D.; Latorraca, N.R.; Lefkowitz, R.J.; Skiniotis, G. Structure of the M2 muscarinic receptor- $\beta$-arrestin complex in a lipid nanodisc. Nature 2020, 579, 297-302. [CrossRef] [PubMed]

63. Yin, W.; Li, Z.; Jin, M.; Yin, Y.-L.; de Waal, P.W.; Pal, K.; Yin, Y.; Gao, X.; He, Y.; Gao, J.; et al. A complex structure of arrestin-2 bound to a G protein-coupled receptor. Cell Res. 2019, 29, 971-983. [CrossRef] [PubMed]

64. Huang, W.; Masureel, M.; Qu, Q.; Janetzko, J.; Inoue, A.; Kato, H.E.; Robertson, M.J.; Nguyen, K.C.; Glenn, J.S.; Skiniotis, G.; et al. Structure of the neurotensin receptor 1 in complex with $\beta$-arrestin 1. Nature 2020, 579, 303-308. [CrossRef] [PubMed]

65. Blomenröhr, M.; Vischer, H.F.; Bogerd, J. Receptor mutagenesis strategies for examination of structure-function relationships. Methods Mol. Biol. 2004, 259, 307-322. [PubMed] 